Dr SRĐAN CVETKOVIĆ, viši naučni saradnik

Institut za savremenu istoriju

Beograd, Republika Srbija

scvetkovic72@gmail.com

UDK 329(497.11)"1945"(093.2)

342.53(497.11)"1945"(093.2)

pregledni $\mathrm{rad} /$ review article

328(497.11)"1945"(093.2)

primljeno / received: 24. 1. 2020.

prihvaćeno / accepted: 20. 5. 2020.

https://doi.org/10.29362/ist20veka.2020.2.cve.151-172

\title{
PROCES ZATIRANJA PARLAMENTARIZMA U SRBIJI I OBLICI PRITISAKA NA OPOZICIJU UOČI IZBORA 11. NOVEMBRA 1945.
}

APSTRAKT: Rad donosi detaljnu analizu predizbornog procesa uoči izbora za Ustavotvornu skupštinu održanih 11. novembra 1945. u Srbiji. Prati se dinamika urušavanja parlamentarne demokratije od strane revolucionarne Komunističke partije skrivene iza Narodnog fronta. Analiziraju se metode $i$ tehnike razbijanja opozicionih partija, gušenja slobode medija i pritisaka i progona kojima su bili izloženi opozicioni političari koji su na kraju pribegli bojkotu kao poslednjem sredstvu političke borbe. Ishod tog procesa bio je ukidanje parlamentarnog poretka i demokratije u Srbiji. Rad se zasniva na analizi onovremene štampe, koja je precizno odražavala proces ukidanja parlamentarizma, kao i na podacima iz literature.

KLJUČNE REČI: Srbija, izbori, demokratija, politička kultura, komunizam, parlamentarizam

Predizborna kampanja uoči izbora 11. novembra 1945. i čistka onih za koje se pretpostavljalo da će biti prepreka uspostavljanju novog društvenog poretka počela je odmah po oslobođenju kroz proskripcije i hapšenja gotovo svih simpatizera starog ,nenarodnog režima“", uz optužbe za kolaboraciju. Nastavljena je kroz akciju „divljeg čišćenja“, to jest masovnim neselektivnim likvidacijama poraženih snaga i protivnika novog režima. Potom, od marta 1945. kroz mnogobrojne procese pred vojnim sudovima i sudovima časti koje je obavezno pratila konfiskacija imovine. Proces je okončan zatiranjem prividnog parlamentarizma i svake vrste opozicije, što je i legalizovano na izborima. Malobrojni srednji, obrazovaniji i imućniji društveni sloj, kao nejaka baza srpske demokratije, tako je različitim političkim i ekonomskim merama sistematski uništavan. Nejaka opozicija i njene vođe u Privremenoj narodnoj skupštini (PNS), ${ }^{1}$ kao i ona vanparla-

\footnotetext{
${ }^{1}$ Privremena narodna skupština (PNS) konstituisana je nešto manje od tri meseca po okončanju rata na Trećem zasedanju AVNOJ-a, 7. avgusta 1945, u skladu sa preporukama Krimske konfe-
} 
mentarna, satanizovana je i etiketirana s ciljem da se stvori atmosfera u kojoj bi bila konačno i uništena. Poslanici su „klasifikovani““ na „,sigurne“, „,kolebljive““ i ,protivnike“, a u njihovim biografijama analiziralo se držanje u toku rata ali $\mathrm{i}$ insistiralo na ,vladanju“ u predratnom periodu. Nije bilo mesta za one koji su označeni kao nosioci „,nedemokratskog“ režima u Kraljevini Jugoslaviji. Mogli su se samo prihvatiti pojedinci iz ,inkriminisanih partija“, ukoliko su u bilo kom obliku sarađivali u borbi protiv okupatora i ,ukoliko se za njihovo uključivanje ukaže stvarna potreba“. Predloženo je da u PNS uđu 53 bivša poslanika kao i neke ličnosti iz javnog života bez stranačke pripadnosti, s tim što se dozvoljavala mogućnost da neki od njih naknadno otpadnu, a neki još neispitani, uđu pojedinačno. Od 359 poslanika, 75 je bilo mrtvih ili u inostranstvu, 182 kompromitovana, a neispitano je ostalo 49 poslanika. $^{2}$

Od predstavnika vlasti moglo se čuti da je opozicija poželjna, ,ali ne ovakva“. Sve ono što nije bilo na liniji Narodnog fronta etiketirano je kao izdajničko i neprijateljsko, a od „saputnika revolucije“ u Frontu se tražilo samo jedno: „Ništa drugo ne tražimo ni od koga nego da sprovodi liniju Narodnog fronta, onaj program koji smo postavili još 1941. koji smo krvlju pisali četiri godine“. ${ }^{3}$ Zakonski projekti, izglasani aklamacijom ogromne većine u PNS-u, davali su osnov za pritisak na opoziciju. Nijedna inicijativa niti amandman opozicije povodom ovih zakonskih projekata nisu usvojeni.

Kao i ostalim zemljama ,narodne demokratije“, primenjivan je sličan repertoar metoda kako bi se potencijalna opozicija oslabila ili uništila. S jedne strane korišćeni su instrumenti državne represije zloupotrebom institucija službi bezbednosti ${ }^{4}$ i zastrašivanjem opozicionih političara, a s druge korupcijom delova opozicionih stranaka. Proces uspostavljanja partijske diktature monopolom na silu, medije i sve institucije bio je dovršen već uoči izbora dok su glasačke kutije bez učešća opozicije na izborima samo bile njena legalizacija. Budući da je opozicija zbog takvih uslova odbila da saučestvuje u činu legalizacije partijske dikta-

rencije. Ona je dopunjavala sporazum Tito-Šubašić zahtevom da AVNOJ bude preimenovan u Privremenu narodnu skupštinu i dopunjen članovima poslednje jugoslovenske Narodne skupštine koji se nisu kompromitovali saradnjom sa okupatorom, kao i traženjem da se svi akti AVNOJ-a podnesu na ponovnu ratifikaciju Ustavotvornoj skupštini. Bio je to zahtev zapadnih faktora, kojim se želelo stvoriti opoziciono jezgro i u ovom telu i na taj način ublažiti komunistička dominacija. Međutim, njihov broj nije bio određen, a primenu sporazuma tj. „filtriranje“ poslanika vršio je Odbor za proširenje AVNOJ-a koji je bio pod potpunim uticajem komunista. Vojislav Koštunica i Kosta Čavoški, Stranački pluralizam ili monizam: obnova i zatiranje posleratne opozicije (Beograd: Privredno-pravni priručnik, 1990), 224-225.

${ }^{2}$ Branko Lazić, Titov pokret i režim u Jugoslaviji (Gornji Milanovac: Dečje novine 1992), 89100; Момчило Павловић, За Тита или за краља. Избори за Уставотворну скупштину 11. новембра 1945. (Београд: Институт за савремену историју, 2019), 97-133; Срђан Цветковић, Између српа и чекића I. Ликвидачија „народних непријатеља“ 1944-1953 (Београд: Службени гласник, 2015), 35-37; Zdenko Radelić, Hrvatska u Jugoslaviji 1945-1991, od zajedništva do razlaza (Zagreb: Hrvatski institut za povijest, Školska knjiga, 2006).

3 „У чему је суштина народнофронтовске идеологије“, Политика, 25. 7. 1945.

${ }^{4}$ U kontroli celokupnog društva u ovom periodu najvažniju ulogu imala je OZNA, prva tajna komunistička policija. Opširnije: Bojan Dimitrijević, „Intelligence and Security Services in Tito's Yugoslavia 1944-1966", Istorija 20. veka, br. 2, (2019), 10-11. 
ture i da bude fasada demokratije pa je pozvala na bojkot, vlast je pribegla nizu metoda kako bi anulirala uticaj bojkota i razbila opozicione partije:

- Nametanje ograničenja opoziciji kroz izborno i medijsko zakonodavstvo. Gušenje slobode političkog delovanja opozicije restriktivnim zakonima o štampi, izbornim i sudskim zakonodavstvom i potpunim monopolom nad medijima, ekonomskim merama pa čak i brutalnom primenom sile.

- Cepanje opozicionih partija i pripajanje prokomunističkih frakcija ili partija Frontu.

- Napadi, zastrašivanja, hapšenja i osude političkih vođa.

- Najzad, u ovakvoj atmosferi, nad oslabljenom opozicijom, preostala je samo formalna egzekucija koja je trebalo da se desi na ,prvim slobodnim i demokratskim izborima“" na kojima nije smelo biti iznenađenja.

\section{Zakonske restrikcije}

Već prilikom izglasavanja izbornog i političkog zakonodavstva u PNSu opozicija je ukazivala na elemente zakona koji mogu biti zloupotrebljeni za obračun sa političkim protivnicima ili za izborne mahinacije. Zakon o biračkim spiskovima, donet 10. avgusta 1945, najavljen je kao najdemokratskiji u istoriji. Zaista je doneo proširenje biračkog prava i opšte pravo glasa, tajno glasanje i prvi put biračko pravo ženama, vojsci i omladini iznad 18 godina. Opozicija je zamerala što je davana mogućnost da i lica sa manje od 18 godina glasaju ukoliko su se nalazila u vojsci, što je otvaralo mogućnost zloupotrebe. Zakonodavci su svoju odluku pravdali sledećim obrazloženjem: „Kad je neko mogao nositi pušku, onda je dovoljno zreo da može i glasati i da bude biran“. 5

Druga primedba opozicije ukazivala je na mogućnost ,proizvoljnog“ oduzimanja biračkog prava. Na osnovu ovog zakona po članu 4 iz biračkog spiska su brisana lica koja su se kompromitovala saradnjom sa okupatorom. Zakon je predviđao amnestiju za osobe za koje se moglo dokazati da je njihovo učešće bilo prinudno ili prividno, kao i za one koji su kasnije pristupili Narodnooslobodilačkoj borbi, ili su je delom pomagali. Odlukom Vlade od 5. septembra 1945. precizirano je da biračko pravo neće imati samo rukovodioci neprijateljskih organizacija, a ne i njihovi obični članovi. Primedbe opozicije su se pre odnosile na implementaciju od strane komisija nego na suštinu zakona, tvrdeći da postoje mnogobrojni slučajevi ,pogrešnog i proizvoljnog tumačenja zakona čime je dovedeno u pitanje biračko pravo hiljada glasača“. Takođe je traženo, radi kontrole, javno obznanjivanje preciznih i detaljnih spiskova brisanih birača po srezovima. ${ }^{6}$ Ukupno je u Jugoslaviji iz biračkog spiska izbrisano 194.158 lica tako da je procenat brisanih birača iznosio 2,3\%. Najviše brisanih bilo je u Bosni Hercegovini i Hrvatskoj, a najmanje u Makedoniji. Demokratija je pisala da se vrše proizvoljne optužbe, anonimne dostave,

\footnotetext{
5 „Председништво и сви одбори АВНОЈ-а изабрани су једногласно“, Политика, 10. 8. 1945.

6 „Изборни закон и изборна стварност“, Демократија, 4. 10. 1945.
} 
ogrešenja o propise, rečju „duh i tendencija je odnela prevagu nad mrtvim slovom zakona“". U nekim selima Podravine i Slavonije procenat brisanih iznosio je i do $30-40 \%$. Opozicija je tražila da se obelodani potpun spisak brisanih po okruzima. Prilikom glasanja za ovaj zakon, 13 poslanika opozicije bilo je uzdržano. ${ }^{8}$

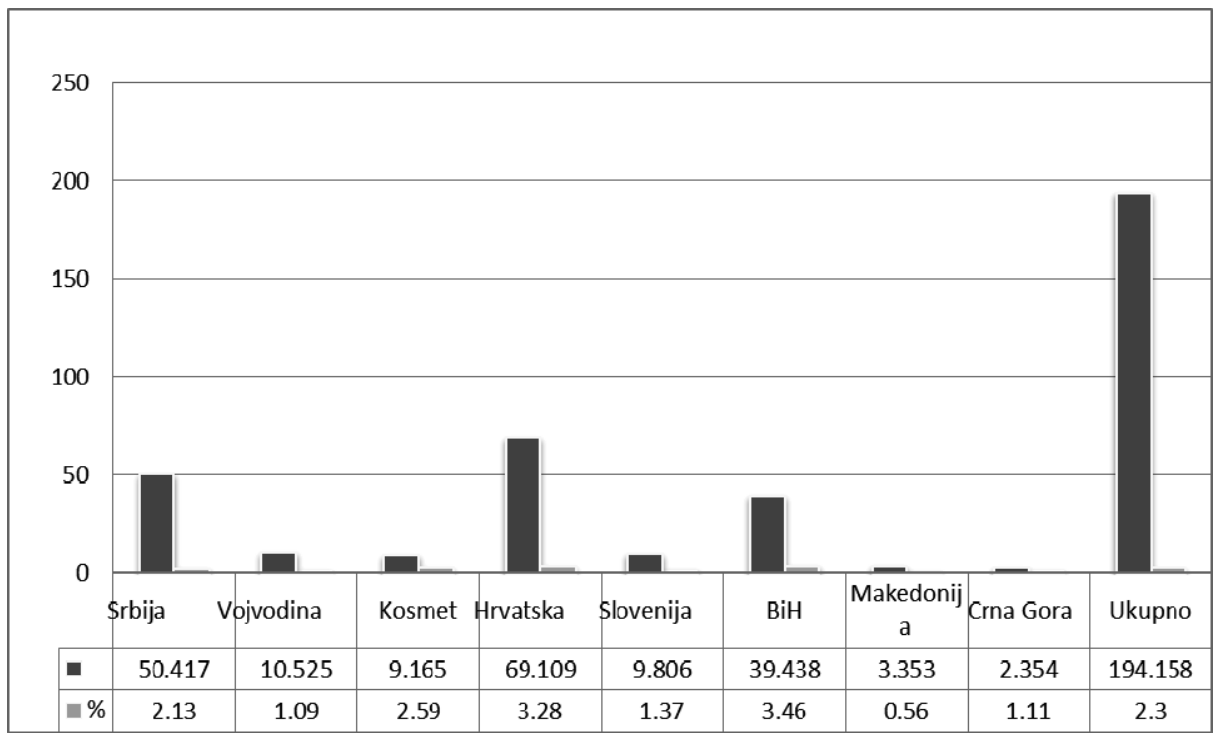

Broj i procenat brisanih birača po republikama i pokrajinama u FNRJ 1945.

Zakon o izboru narodnih poslanika, izglasan 22. avgusta 1945, takođe je naišao na oštre kritike opozicije iako ga je Edvard Kardelj ocenio kao ,jedan od najdemokratskijih zakona koji danas postoji“. Tripko Žugić, poslanik Demokratske stranke (DS), izneo je u raspravi primedbe na komplikovanost procedure prema kojoj se odjednom biraju poslanici za dva doma sa dva različita merila. Pored toga, iako su se izbori odvijali na tri nivoa, sreskom, okružnom i saveznom, sva preimućstva srazmernog predstavništva davao je saveznim listama. Uslov za postavljanje zemaljske liste bio je potpis 10 lica iz 2/3 srezova i najmanje polovine izbornih okruga federalne jedinice, odnosno oblasti. Izbori za Saveznu skupštinu vršili su se na osnovu okružnih lista, u kojima je svaki izborni srez mogao imati jednog ili više kandidata. Na svakih 40.000 stanovnika dolazio je jedan poslanik.

Zamerka opozicije se odnosila na to da su ovakvi izborni uslovi za isticanje saveznih lista bili ozbiljna prepreka za sve stranke, s obzirom na njihov regionalni karakter i situaciju u kojoj su pojedine pokrajine bile nepristupačne opozicionim strankama, kao i okolnosti u kojima je bilo teško organizaciono

\footnotetext{
${ }^{7}$ Исто.

${ }^{8}$ Nakon Oktobarske revolucije u SSSR-u boljševici su oduzeli biračko pravo „reakcionarnom“ stanovništvu u sličnom procentu. Tamo je oko 5\% stanovništva izgubilo biračko pravo, a čovek bez političkih prava pogrdno je nazivan „lišenjec“. С. Цветковић,
} 
obnavljanje opozicionih stranaka. Režim, budući da je imao u rukama celokupan državni aparat, bio je u privilegovanoj poziciji. ${ }^{9}$ Još jedna načelna primedba opozicije odnosila se na činjenicu da su izbore sprovodili organi koji nisu imali pravi legitimitet budući da su izabrani u vanrednim okolnostima i na nelegalan način. Naglašavano je da obnovu demokratije treba započeti „odozdo“, izborom narodnih odbora, kako je isticao Dragić Joksimović, predstavnik DS u Zakonodavnom odboru, prilikom obrazlaganja Zakona o izboru narodnih poslanika. Sumnju je budila i ustanova naknadne primedbe na listu kandidata, kao i mogućnost ,proizvoljne cenzure“ pod izgovorom onemogućavanja kandidovanja „reakcije“. Protiv ovog zakona glasalo je 16 poslanika opozicije. ${ }^{10}$

Zakon o udruženjima, zborovima $i$ drugim javnim skupovima, izglasan $\mathrm{u}$ PNS-u 25. avgusta 1945, izazvao je podozrenje zbog odredbe da čak i stare stranke moraju da ponovo traže odobrenje za rad, kao i da se svake godine podnosi izveštaj o godišnjim materijalnim izdacima. U Demokratiji se povodom toga pojavio članak „Da li je Zakon o udruženjima pravljen samo za opoziciju!?“‘. U njemu se autor pita zašto se još uvek nije čulo da su vlastima prijavile svoje postojanje Komunistička partija i stranke u Frontu, ili ako se smatra da su ulaskom u Front prestale da postoje zašto se ne registruje sam Front? Na kraju se postavlja pitanje: Da li vlada smatra da zakoni važe samo za opoziciju a za nju ne? ${ }^{11}$

Zakon o štampi, usvojen u PNS-u 19. avgusta 1945, od ogromnog značaja za slobodno delovanje partija, plasiranje njihovih ideja i kritičkih pogleda, predviđao je vrlo restriktivne odredbe kako u pogledu mogućnosti izdavanja i uređivanja tako i sadržaja štampe. Stroge inkriminacije zakona široko su određivale kategorije lica koja ne mogu biti urednici ili izdavači novina. Postojala su brojna i neodređena sadržinska ograničenja na liniji zaštite tekovina revolucije koja su mogla biti ocenjena kao verbalni delikt. Od ukupno 27 članova zakona 4 su se odnosila na zabrane, a 11 na kaznene odredbe. Naročito je bio bitan faktički monopol države na štamparije, kao i na proizvodnju i distribuciju hartije, ali i samih novina, ostvaren pre svega različitim oblicima oduzimanja privatne svojine (konfiskacija, nacionalizacija itd.). ${ }^{12}$

Dragić Joksimović (DS) je izvestio Zakonodavni odbor da će opozicija (17 poslanika) glasati protiv ovog zakona, jer smatra da daje velika ovlašćenja javnom tužiocu i vrlo restriktivno tretira ovu oblast. Težnja opozicije za liberalizacijom štampe sudarala se sa revolucionarnim težnjama Komunističke partije. Veoma važan za funkcionisanje pravne države i za izborni proces bio je i Zakon o narodnim sudovima koji je bio trn u oku opoziciji, jer je kao prvi zadatak sudova vrlo neodređeno postavljao zaštitu tekovina Narodnooslobodilačke borbe. Uticaj izvršne vlasti i partijske kontrole nad sudstvom i laiciziranje kadrova bili

\footnotetext{
${ }^{9}$ Исто, 158.

10 „Изборни закон и изборна стварност“, Демократија, 1, 27. 9. 1945.

11 „Да ли је Закон о удружењима прављен само за опозицију!?“, Демократија, 27. 9. 1945.

12 Službeni list DFJ, br. 65/1945, 1. 9. 1945. Ovaj zakon je bio potvrđen od strane Narodne skupštine FNRJ 1946 (Službeni list FNRJ, br. 56/1946), a izmenjen 1948. godine (Službeni list FNRJ, br. 105/1948). Uvodnim zakonom za Krivični zakonik iz 1951. došlo je do njegove liberalizacije (Službeni list FNRJ, br. 11/1951).
} 
su očigledni, što je vanfrontovska opozicija u svakoj prilici naglašavala. Umesto podele vlasti isticano je načelo jedinstva vlasti. Istovremeno u praksi se sve više gledalo na pravnike i profesionalne sudije pa i advokate kao na konzervativni element i ,reakciju“ koju treba prevaspitati. ${ }^{13}$

\section{Cepanje političkih partija}

Jedna od tehnika kojom se Komunistička partija služila, a koja je viđena i u drugim zemljama u procesu uspostavljanja komunističke dominacije, jeste izazivanje raskola $\mathrm{u}$ opozicionim partijama uz pripajanje prokomunističkih frakcija Frontu i likvidaciju njihovih jezgara. Najpre su rascepi izazivani u partijama van Fronta, a u nastavku procesa zatiranja parlamentarizma - i u partijama u Frontu. Legitimnost političkih stranaka van Fronta najčešće je osporavana na taj način što su krila ili pojedinci u Frontu (inače često marginalne ličnosti) predstavljali sebe kao autentične predstavnike stranačke politike a ostale van Fronta oglašavali kao disidente i raskolnike, u čemu su imali punu podršku režima. Pritom su, bez znanja javnosti, primani u članstvo Komunističke partije, da bi kao nagradu za obavljene zadatke u vlastitoj nekomunističkoj stranci dobijali visoke državne položaje. Nepotpisani komentator u Politici kaže: „Borbeni i slobodoljubivi članovi Demokratske stranke nalaze se u frontu, radikali Miše Trifunovića odustali su od učešća na izborima jer su svesni da je od Radikalne stranke ostalo samo ime, i ova grupa dala je lep broj čestitih ljudi Narodnom frontu. U javnosti je ubačeno ime Mihaila Gavrilovića kao vođe zemljoradnika, međutim Zemljoradnička stranka nalazi se u Frontu i ona je za to dobila odobrenje svojih pristalica“. ${ }^{14}$

Predstavnici Demokratske stranke u Narodnom frontu, posle odluke Milana Grola o izlasku iz Vlade i apstinenciji opozicionih stranaka (20. septembra 1945), održali su 28. septembra 1945. sastanak na kome su osudili bojkot, Grolove stavove i rad i izabrali Akcioni odbor od deset članova. Odlučili su da kandiduju svoje predstavnike na izborima za Konstituantu na listi Narodnog fronta, uputivši Proglas članovima Demokratske stranke. Izvršni akcioni odbor, između ostalog, u proglasu kaže: „Glasajući za poslaničke kandidate na čijem je čelu nosilac liste Maršal Tito, vi demokrati, odužujete se svim žrtvama, braći, majkama i sestrama i svojim sinovima koji poginuše za slobodu domovine." ${ }^{15}$ Dat je kritički osvrt na delovanje rukovodstva stranke od poslednjeg kongresa (15. marta 1939). Učesnici konferencije smerali su, zapravo, da obnove organizaciju paralel-

${ }^{13}$ Pored ovih, kao važni za izbore doneti su Zakon o ustavotvornoj skupštini (21. avgusta 1945) koja je zamišljena kao dvodomna te su se imali birati poslanici za Savezno veće i Veće naroda, kao i Zakon o oduzimanju državljanstva oficirima i podoficirima jugoslovenske armije koji se ne vraćaju u zemlju (23. avgusta 1945). „Изборни закон и изборна стварност“, Демократија, 27. 9. 1945.

14 „Апстиненција реакције“, Политика, 22. 9. 1945.

15 „,Апстиненција ће ликвидирати г. Грола и његову лажну демократију“, Политика, 26. 9. 1945 ; „Делегати из свих крајева осудили су рад Милана Грола и његове околине“, Политика, 28. 9. 1945. 
nu Demokratskoj stranci, čiji je rad već bio odobren od strane nadležnih vlasti i isticali da se još Ljuba Davidović zalagao za Narodni front. Od opozicionih stranaka DS je imala najveći uticaj (sputavan i ograničen u velikoj meri) koji se izražavao kroz delovanje poslanika u PNS-u, kao i u tiražu partijskog glasila Demokratija. Otuda nije ništa neobično što je režimska štampa, Politika a naročito Bor$b a$, davala veliki prostor konferencijama i izjavama demokrata u Frontu kojima je napadana legalna Demokratska stranka. Glavne perjanice demokrata u Frontu bili su Miloš Carević i Vlada Zečević, tadašnji ministar unutrašnjih poslova. U izjavama u štampi Carević je tvrdio da Grol nije mogao da podnese prijavu u ime Demokratske stranke kojom se traži odobrenje rada, jer od 1939. nije održan nijedan kongres. Smatrao je da grupa van Fronta nema legitimitet i da nikog ne predstavlja, a ponajmanje narod, jer je na osnovu prijave sastavljena samo od ljudi iz Beograda, gde gotovo svi pripadaju inteligenciji (i to ,nepoštenoj“‘), dok su potpisana samo tri radnika i tri zemljoradnika. ${ }^{16}$

Sličan proces se desio u Zemljoradničkoj stranci (ZS), s tom razlikom što se njen lider Mihailo Gavrilović nije vratio iz emigracije i obnovio politički rad. Potpredsednik stranke Marko Vujačić ovako je govorio o bivšem lideru: „Ličnost Mihaila Gavrilovića je takva da ga je njegova politička prošlost i vaspitanje udaljilo od seljaka i stvorilo nedostatak smisla za rad sa seljačkim masama. On je uvek važio za stranog čoveka u stranci da ne kažem ubačenog u stranku."17 Predsednik Glavnog odbora ZS u Frontu Kosan Pavlović-Brđanski iz Stepojevca obrazlagao je da je ova partija ,pristupila Narodnom frontu zbog idejne sličnosti s političkim strankama i grupama u Frontu“. ${ }^{18}$ Međutim, vrlo brzo pred izbore došlo je do razlaza u frakciji u Frontu, pa je početkom novembra 1945. Mita Stanisavljević, jedan od potpredsednika stranke i predsednik Zemljoradničkog poslaničkog kluba u PNS-u, dao izjavu o istupanju iz Fronta. Ovakva odluka je usledila u nastojanju da se sačuva ugrožena stranačka samostalnost, kao i zato što je rukovodstvo onemogućavalo da se sastanu glavni organi stranke. Narodni front je odbio da ZS istakne posebne stranačke liste na izborima i osudio što su se pojedini članovi kandidovali bez odobrenja stranke. Po Stanisavljeviću, Front se pretvarao od kompozitne organizacije u monolitnu i jednostranačku, a ekonomska politika (posebno zadružna politika) nije usklađena sa interesima naroda, te stoga stranka treba da ostvaruje program van Fronta.

Grupu radikala u Narodnom frontu, koji se nisu mogli pohvaliti naročitim uticajem, predvodio je Mihailo Đurović koji se obratio u ime radikala na Prvom kongresu Narodnog fronta. Bilo je pokušaja da se manipuliše i autoritetom ostarelog lidera radikala Ace Stanojevića s kojim je maršal Tito upriličio susret krajem jula 1945, upravo pred početak kongresa. Zamenik predsednika radikala Miloš Trifunović vratio se u zemlju, ali je odbio bilo kakvu saradnju sa Narodnim fron-

\footnotetext{
${ }^{16}$ Ova izjava pokazuje da je bilo vrlo teško obnoviti rad opozicionih stranaka van Beograda, kao i da je jezgro opozicije bilo sastavljeno mahom od ljudi slobodnih profesija koji nemaju veze sa državnom službom. Борба, 23. 9. 1945.

17 „Седница Главног одбора Народне сељачке странке“, Политика, 23. 9. 1945.

18 Политика, 4. 10. 1945.
} 
tom i Titom (protiv njega je pokrenut sudski proces za izdaju tokom 1946). Međutim, uticaj radikala i njihova aktivnost, za koje je vezivan „nenarodni““ režim pre rata, bili su sasvim slabi. Drugi ugledni lider ove partije, Lazica Marković, uhapšen je zajedno sa Kostom Kumanudijem i osuđen u procesu Dragoljubu Mihailoviću jula 1946. na šest godina zatvora. Uhapšen je po drugi put 5. oktobra 1945. (prvi put je zatvoren novembra 1944) zbog potpisivanja Apela srpskom narodu 13. avgusta $1941,{ }^{19}$ reakcionarnih spisa u toku rata, naročito spisa Novo ili staro, kao i potpisivanja Deklaracije udruženih srpskih stranaka, kojom se udara na tekovine NOB-a i ,raspiruje međunacionalna mržnja“ ocenama da je partizanski pokret „ustaško-hrvatski u boljševičko-partizanskoj formi“. Već sledećeg dana protiv Markovića je u Politici osvanuo pamflet preko cele strane u kojem je analiziran njegov izdajnički rad tokom okupacije i posle oslobođenja. ${ }^{20}$

Samostalna demokratska stranka (SDS) bila je pocepana na krilo generalnog sekretara Save Kosanovića (ministra informisanja), Srđana Budisavljevića (namesnika) i potpredsednika SDS Hinka Krizmana kojima je dat pun legitimitet da predstavljaju stranku i koji su iskreno sarađivali u Frontu, dok se tome usprotivio Vjećeslav Vilder, koji je ostao u inostranstvu. U zemlji je osudio ulazak SDS-a u Front Duda Bošković - lider SDS-a iz Vojvodine, izražavajući neslaganje sa koncepcijom privrednih i političkih reformi. Demokratija je objavila izveštaj sa sednice Glavnog i Izvršnog odbora SDS-a od 15. septembra 1945, koji osuđuje delatnost dr Hinka Krizmana i Save Kosanovića unutar Fronta i izjavljuje da će SDS sarađivati sa demokratskim strankama izvan Fronta, dok je režimska štampa pun publicitet i legitimitet davala krilu u Frontu. ${ }^{21} \mathrm{Na}$ izborima nisu uzele učešća ni Socijalistička ni Socijaldemokratska stranka, koje nisu istakle svoje kandidate.

Na osnovu dostupne dokumentacije, zaključujemo da je OZNA budno motrila i obrađivala vodeće stranačke prvake opozicije. O njima postoje sačuvani detaljni elaborati i karakteristike o vladanju pred i u toku Drugog svetskog rata. Postoje detaljni spiskovi članova glavnih odbora, svih članova stranaka $i$ karakteristike za viđenije prvake po srezovima. Iz građe se takođe vidi da OZNA nije birala sredstva i da je ljude iz kvislinškog aparata poput Dragog Jovanovića, prvog policajca Nedićevog režima, koristila kako bi eventualno diskreditovala pojedine stranačke aktiviste, pre svega Demokratske stranke. ${ }^{22}$

Pošto su neprijateljski delovi stranaka, odnosno stranke van Narodnog fronta postepeno likvidirani, delovi stranaka $\mathrm{u}$ Frontu su se potom utopili $\mathrm{u}$ Front uz korišćenje raznih sredstava prinude i na taj način brže ili sporije de facto prestajali da postoje. Pristupanje Frontu različitih stranaka ili njihovih frakcija, osim ideoloških sličnosti u zalaganju za federaciju, republiku, demo-

${ }^{19}$ Proglas Apel srpskom narodu, objavljen u listu Novo vreme, inicirala je komesarska vlada Milana Aćimovića. Potpisalo ga je nekoliko stotina političara i javnih ličnosti apelujući na red i mir kako se ne bi provocirale nemačke odmazde i represalije. „Апел српском народу“, Ново време, 13. 8. 1941.

${ }^{20}$ Политика, 5. 10. 1945.

${ }^{21}$ Демократија, 4. 10. 1945.

22 Arhiv Srbije, Fond BIA, II, Delatnost i rad građanskih političkih stranaka. 
kratizaciju, antifašizam i socijalne reforme, imalo je i lukrativne lične i stranačke razloge. Drugo, vlast je preko tajne policije pribegla zastrašivanjima i korupciji kojima je teško bilo odoleti. Male stranke sa neznatnim brojem ili bez poslanika u predratnim skupštinama našle su se prvi put u poziciji da vrše vlast raspolažući ministarskim i poslaničkim funkcijama. Pojedine ličnosti iz krupnih građanskih stranaka, ponesene ličnom ambicijom i žeđu za vlašću, nisu bile otporne na blagodeti koje donosi učešće u vlasti ili pak na mogućnost da postanu uticajni stranački lideri. Neki su od njih bez sumnje bili zastrašeni ili zavrbovani od službe državne bezbednosti koja je bdila nad društvenim životom.

\section{Napadi i zastrašivanja}

Druga metoda kojom se vlast koristila u obračunu sa političkim protivnicima bili su bespoštedni napadi i zastrašivanje opozicionih stranaka uz korišćenje i zloupotrebu državnih institucija (vojske, policije, sudova). Naročito su bili izraženi pred izbore. Prljava ili „divlja“ kampanja, kako je Grol naziva, trebalo je da stvori atmosferu izbora između oslobodilaca-antifašista i formalne „,buržoaske demokratije“, reakcije i izdajnika oličenih u opoziciji. Štampa je obilovala naslovima i etiketama koji su diskreditovali opoziciju tokom cele 1945, ali naročito od izlaska Milana Grola iz Vlade i odluke o izbornoj apstinenciji udružene opozicije. U odsustvu slobode medija oblikovalo se javno mnjenje gde je trebalo da izbori budu samo formalna egzekucija narodnih neprijatelja. Režimska štampa je bila zasićena jednostranom i prljavom kampanjom režima. Jedini opozicioni list u Srbiji bio je nedeljnik Demokratija (koji je izašao u samo sedam brojeva). Kada se piše o opoziciji u režimskoj štampi, govori se samo u negativnom svetlu u patuljastim člancima, dok se aktivnosti lokalnih lidera Narodnog fronta prate sa pompom i preko celih strana. Izveštaji sa mitinga $\mathrm{i}$ manifestacija donose se na celoj naslovnoj strani sa detaljnim opisima $\mathrm{i}$ izjavama čak i beznačajnih učesnika, dok se aktivnost opozicije gotovo i ne pominje. Posredstvom medija kreirala se atmosfera kao da rat nije završen i da svakog ko nije na idejnoj liniji fronta treba eliminisati.

Donosimo samo neke najzanimljivije primere iz javnih nastupa koji dočaravaju predizbornu atmosferu i oblike pritisaka i zastrašivanja političkih protivnika i neistomišljenika:

„Tu smo opoziciju u ratu tukli ne gumenim nego onim pravim čeličnim kuglicama.“ (Milovan Đilas na mitingu na Slaviji, 7. oktobra 1945, pred 70.000 ljudi). ${ }^{23}$

„Učinimo sve da zagorčamo život i onako gorak našoj takozvanoj opoziciji.“ (Aleksandar Ranković na istom mitingu).

„Reakcija hoće da skrene pažnju na izbor Tito ili Kralj. Mi ne idemo linijom Tito ili Kralj iz prostog razloga što smatramo da je pitanje monarhije ili republike faktički rešeno $u$ dosadašnjoj borbi... Radi se o tome da $u$ drugim

\footnotetext{
${ }^{23}$ Политика, 8. 10. 1945.
} 
uslovima i drugim sredstvima nego što smo se služili u ratu završimo i krunišemo pobedom.“" (Milovan Đilas, 7. septembra 1945). ${ }^{24}$

„Ono što imamo pred očima i nije opozicija nego reakcija - zima koja se otima od zahvata mladog proleća. Opozicija gura točak istorije, reakcija ga zaustavlja. Opoziciju nose mladi ljudi reakcija dolazi od starih." (Josip Broz Tito, 26. septembra 1945). ${ }^{25}$

„Ali da je pobedio Draža Mihailović mi ne bismo uopšte imali mogućnost da budemo u opoziciji, jer niko od nas ne bi bio živ... Pravo je čudo da narodna vlast nije eliminisala više ljudi... S Frontom ne mogu ići oni koji vuku napolje ili oni od kojih svak vuče za sebe... Pristalice Demokratske stranke nisu uzimale učešća u oslobodilačkoj borbi nego su se u zemlji i na strani držali neprijateljski.“ (Dragoljub Jovanović, lider Narodne seljačke stranke, na pitanje stranih novinara o brisanju iz biračkog spiska, 29. septembra 1945). ${ }^{26}$

„Mi moramo smrdljivu lešinu reakcije maknuti s našeg puta. Sredine nema i ne može da bude! Ko ne glasa za Narodni front, taj će da glasa protiv naroda i nezavisnosti Jugoslavije! Taj će glasati za zločince i koljaše. Taj će glasati za fašističke i četničke uniforme, za najveću izdaju koju je srpski narod ikada doživeo.“ (Moša Pijade, 1. oktobar 1945). ${ }^{27}$

„Samo šaka onih koji su se svojim radom ogrešili o narodne interese... neće moći učestvovati na izborima, ali ti elementi još ne miruju i pokušavaju da nagovore i druge da sa njima ne glasaju no, oni koji poslušaju poziv ovih nenarodnih elemenata rđavo će se provesti.“ (miting Narodnog fronta u Petrovcu, Reč naroda, 12. oktobar 1945). ${ }^{28}$

Koča Popović na jednom mitingu ovako komentariše primedbe opozicije o „nesmirenoj atmosferi“ i neregularnosti izbora: „U stvari njoj smeta to što atmosfera nije dovoljno uznemirujuća, što voda nije dovoljno mutna da u njoj love i ulove vlast“ ${ }^{29}$ Po ustanovljenju ,kutije bez liste“" otvoreno se pretilo neistomišljenicima: „U treću kutiju ubaciće kuglicu onaj koji je protiv nacionalnih i oslobodilačkih tekovina NOB-a, protiv ravnopravnosti jugoslovenskih naroda i agrarne reforme. “30

U predizbornu kampanju aktivno su se uključile sve državne institucije i društvene organizacije koje su listom bile pod kontrolom KPJ. Uobičajeno je bilo da sa građanima mitinguje i vojska, a oficiri otvoreno agituju za Front:

,$\ldots$ Na zajedničkom mitingu vojske i građana u Valjevu masa je oduševljeno klicala Titu, bratstvu i jedinstvu, KPJ...".31

\footnotetext{
${ }^{24}$ Политика, 7. 9. 1945.

25 „Још један издајнички акт“, Политика, 26. 9. 1945, 1.

26 „Изјава др Драгољуба Јовановића представницима стране штампе“, Политика, 29. 9. $1945,7$.

${ }^{27}$ Демократија, 4. 10. 1945.

${ }^{28}$ Исто, 1. 11. 1945.

${ }^{29}$ Политика, 29. 10. 1945.

${ }^{30}$ Исто, 2. 11. 1945.

31 „Заједнички митинг војске и народа у Ваљеву“, Политика, 5. 9. 1945.
} 
„Naša armija stoji čvrsto uz Narodni front!“ (major Branković na zboru u Požarevcu, 6. septembra 1945). ${ }^{32}$ „Narodni front je stvoren još pre rata u borbi protiv nenarodnog režima bivše Jugoslavije... “, izjavio je general Kosta Nađ na mitingu u Zemunu 23. septembra 1945. ${ }^{33}$

Na spisku finansijera kampanje Narodnog fronta nalazila su se i takva udruženja kao što su Mesni odbor radnika pravosudnih i upravnih ustanova (priložio 1.440 dinara), Novinarsko udruženje federalne Srbije (3.000 dinara), državna preduzeća (npr. „Prosveta“ koja je priložila 10.000 dinara), kao i razna sindikalna veća državnog sindikata. Predizborne konferencije su se često održavale po školama uz obavezno masovno prisustvo prosvetnih radnika, đaka i roditelja. Politika od 6. oktobra 1945. donosi poziv učenicama Treće ženske gimnazije da se okupe radi odlaska na miting omladine Narodnog fronta. $\mathrm{Na}$ zborovima prosvetnih radnika i nameštenika govore poslanički kandidati kao i predstavnici vojske. ${ }^{34}$ U Požarevcu, direktor gimnazije je pozivao sve učenike da prisustvuju konferenciji Narodnog fronta. „Veliki broj učenika i učenica iste gimnazije pozvan je na odgovor zato što nisu prisustvovali (a bilo je naređeno) jednom predizbornom mitingu Narodnog fronta. Sam direktor je vršio saslušavanja“. Časopis za decu Pioniri potpuno je politički obojen i bez ikakvih uvijanja piše da su i ,pioniri u Narodnom frontu!“. Ide se dotle da se u školama priređuju predizborne konferencije, u kojima se pokazuje kako bi deca glasala za Narodni front kad bi imala prava. U srednjim školama, funkciju agresivne političke propagande i nadzora nad omladinom vršio je USAOJ. ${ }^{35}$

Izveštaji u štampi dočaravaju i predizbornu atmosferu. Ovako je izgledao jedan od predizbornih mitinga omladinaca pred zgradom Tehničkog fakulteta: ,,... Pred jednom grupom išao je nemački vojnik sa transparentom u rukama: 'Glasam za Grola!', iza njega sa krunama na glavi idu kralj i kraljica a oko njih D. Mihailović i P. Živković, ustaša sa krvavom kamom u rukama i žandarm s pendrecima“" ${ }^{36}$

U članku „Naprasno demokratisanje“ „nepristrasni“ komentator Politike oštro napada opoziciju: „Oni, međutim, ne ćute već traže slobodu... A kakvu slobodu traže. Zakonitost Vidovdanskog ustava, koji su za pare od begova kupili? Zato bi trebalo sad da pospu glavu pepelom i da kažu: kako smo radili ipak smo dobro prošli...". 37 Prema pisanju opozicione Demokratije, dok je bilo dovoljno da demokrat Grol izađe iz vlade i bude oglašen fašistom dotle su mnogi jerezovci „preko noći postali antifašisti prve klase“. Kritikujući ovu društvenu pojavu list objavljuje slikovitu satiričnu pesmu ,Novi čovek“‘.:38

Radikal sam bio i biću / Demokrata? Ako treba!

Jerezovac? Ko grom s neba! / A kolonǎ̌? K dobrom piću...

\footnotetext{
${ }^{32}$ Исто, 7. 9. 1945.

33 „Народни фронт је створен још пре рата у борби против ненародног режима старе Југославије“, Политика, 24. 9. 1945.

${ }^{34}$ Демократија, 1. 11. 1945.

${ }^{35}$ Исто, 25. 10. 1945.

${ }^{36}$ Политика, 14. 10. 1945, насловна страна.

${ }^{37}$ Политика, 30. 9. 1945.

38 „Нови човек“, Демократија, 18. 10. 1945.
} 
Pa ko velim: svejedno je / Šta je ovaj, onaj ko je

Glavno da je svaki naš! / A svi puti u Rim vode

Kad se čovek drži mode / Ja sam druže sad - / Frontaš!

Tokom septembra 1945, Tito se na naslovnoj strani Politike i u krupnom planu pojavio čak 16 puta, a Grol nijednom, a kada je i pominjan u vrlo kratkim člancima to je bilo samo u negativnom kontekstu. „Apstinencija će likvidirati gospodina Grola i lažnu demokratiju“, glasi naslov nepotpisanog komentara na prvoj strani Politike 27. septembra 1945. godine. Svaki broj donosio je karikature čelnika opozicije i „reakcije“, dok šale na račun Fronta nisu zbijane. U jednom broju Politika donosi karikaturu na kojoj Grol šiša D. Mihailovića uz rečenicu: „Udesiću te da niko i ne sluti kakav ste demokrata“. ${ }^{9}$ Demokratija postavlja pitanje vlastima, pošto se slušaoci Radio Londona i Radio Njujorka kvalifikuju kao najveći reakcionari, dok su do juče obeležavani kao komunisti: „Da li su jučerašnji komunisti prerasli u reakcionare ili su se reakcionari za vreme Nemaca kamuflirali u komuniste?“40

Predizborne parole i slogani Narodnog fronta takođe su bili izuzetno agresivni i u duhu produžavanja građanskog rata „drugim sredstvima“:

„Narod bi morao da ratuje protiv ustavotvorne skupštine koja bi dovodila $u$ pitanje te tekovine“ (Moša Pijade u Zakonodavnom odboru, 15. avgust 1945).

„Drugovi, Ozna je sjajna stvar a i milicija nije rđava... “ (M. Đilas na Centralnom odboru USAOJ-a, Politika, 7. septembar 1945).

„Pravdu treba da dele ljudi koji znaju da čuvaju tekovine NOB-a...“ (Miloš Minić na Zakonodavnom odboru, Politika, 5. septembar 1945).

„Nećemo valjda da Srbiju zastupa Draža...“ (Sreten Žujović, miting na Karaburmi, 10. novembar 1945).

„Demokratska opozicija - politički organizator špekulacije i crne berze!“41

„Dole Grol fašista“, „Smrt Grolu!“, „Grola i Peru o banderu!“, „Kuršum Grolu! ‘42

Osim verbalnih pretnji bilo je dosta otvorenih napada pa i pojedinačnih ubistava. U selu Umčari kod Beograda brutalnom akcijom skojevaca pretučen je i praktično ubijen učitelj Svetozar Dunjić. Krivica mu je bila, osim što je bio ideološki i klasno nepodoban, to što nije došao na miting Narodnog fronta 6 . oktobra 1945. Prebijen je iste noći od strane skojevaca koje je predvodio Moma Marković, zajedno sa izvesnim Tomićem, i ubrzo je preminuo. ${ }^{43} \mathrm{O}$ izbornoj atmosferi rečito govore i mnogi dokumenti u Sloveniji i Hrvatskoj iz kojih se vidi da je takva praksa

39 Политика, 9. 9. 1945. Sreten Žujović se protivio postavljanju protivkandidata u 2. rejonu rečima: „Ama kome je palo na pamet da postavlja više kandidata? Ne zovemo mi građanina da bira nego da glasa!“ “.. U trenutku pitao sam se: s kim sam se uhvatio u kolo i kuda sve to vodi?!“‘. Драгољуб Јовановић, Медаљьни, књ. IV (Београд: Службени гласник, 2015), 216 217 (Медаљон Сретена Жујовића).

40 Демократија, 18. 10. 1945.

${ }^{41}$ Исто, 4. 10. 1945.

${ }^{42}$ Исто, 18. 10. 1945.

43 Живка С. Дуњић, Умчари (Београд: Културно просветна заједница Србије, 2019) 159-164. 
bila širom zemlje. Tako je u Bosanskom Šamcu tri dana pred izbore čak streljano dvadesetak ljudi koji su agitovali protiv režima ili bili sumnjivi vlastima. ${ }^{44}$

\section{Sloboda štampe i političkog delovanja}

Formalno obnavljanje rada skoro svih građanskih stranaka nije značilo i obnovu parlamentarizama u punom smislu te reči. To je, inače, nezamislivo bez elementarne slobode medija i slobode političkog delovanja. Osim HRSS-a u Hrvatskoj, nijedna politička stranka nije uspela u značajnijoj meri da obnovi stranačku organizaciju. Narodni front je u potpunosti ispunio politički prostor i nije dozvoljavao organizovanje opozicije i ispovedanje separatnih političkih programa od onih koji su usvojili Narodni front i KPJ. Nemogućnost organizacionog obnavljanja stranaka pratilo je odsustvo slobode štampe i potpuna kontrola svih drugih medija. Ona se ogledala u potpunom monopolu KPJ na štampu i radio-program. Samo dve stranke u Frontu su bile u mogućnosti da putem svoje štampe izlažu program. Bilo je svega nekoliko neuspelih pokušaja vanfrontovske opozicije da pokrene svoja glasila.

Kao listovi stranaka u Frontu izlazila su nešto duže samo dva nedeljnika. List Republika štampan je od novembra 1945. do oktobra 1956, kao glasilo Republikanske stranke čiji je vlasnik i izdavač bio Vladimir Simić. Ispoljavao je tek izvesnu dozu samostalnosti i kritičkih pogleda na stvarnost. Povremeno je napadan od partijskih jurišnika, a njegova reprodukcija otežavana (otkazivanje pretplate revizora tokom 1947-1948). Ipak, budući da je subvencionisan iz kase Narodnog fronta, zahvaljujući opreznom načinu izveštavanja, kao i izrazitoj samocenzuri, održao se do zatiranja 1956. i bio u tadašnjoj medijskoj monolitnosti jedina oaza kakve-takve slobodne misli za ljude koji nisu sasvim delili poglede režima. ${ }^{45}$ List je zvanično ugašen zbog „materijalnih poteškoća“, naročito kada je Politika od aprila 1956. počela da izlazi i utorkom - danom u kojem je izlazila Republika. Drugi list, Slobodni dom izdavala je HRSS, jedina stranka kojoj je bilo dopušteno da potpuno razvije svoju stranačku organizaciju. Bila je to svojevrsna transmisija KPJ na hrvatskom selu, gde je trebalo da suzbija uticaj Vladka Mačeka. List je bio potpuno prorežimski i održao se čak do 1963. (kada je ugašen takođe zbog ,materijalnih poteškoća"). Stranka je uspela da jedno vreme razvije sreske i mesne odbore u Bosni, pa je Odbor HRSS za Bosnu i Hercegovinu izdavao izvesno vreme list Hrvatski glas.

44 „Dana 8. XI. došao je član brigadnog komiteta drug kapetan Krajačić... Odmah me je pozvao i objasnio stvar, da su oni imali 7. XI. sastanak u brigadi kojem je prisustvovao jedan drug iz Armije i dao im direktive, po kojima se ima odmah postupati t. j. da se preko članova K. P. iz neprijateljskih sela pokupe najgori koji bi djelovali na mase da ne idu na glasanje i da se isti potuku, iste moraju hapsiti samo članovi K. P. ili SKOJ-a. Pohapsili smo 8. na 9. XI. 12 iz Šamca i Kruševice. 9. na 10. XI. 10 iz Sikirevaca i Jaruge. Isti su potučeni niže Šamca i bačeni u Savu, gdje je sam Krajačić rukovodio i tukao...". Partizanska i komunistička represija i zločini u Hrvatskoj 1944-1946: dokumenti, priredili Zdravko Dizdar, Vladimir Geiger, Milan Pojić, Mate Rupić (Slavonski Brod: Hrvatski institut za povijest - Podružnica za povijest Slavonije, Srijema i Baranje, 2005), 300.

${ }^{45}$ Dragoljub Jovanović svedoči da je u kaznioni u Sremskoj Mitrovici čak i list Republika tretiran kao opozicioni list i bio zabranjen za čitanje posle 1952. godine. Д. Јовановић, н. д., 115. 
Od stranaka van Fronta najdublji trag ostavila je Demokratija, nedeljni list Demokratske stranke. List je izlazio od 27. septembra 1945. do 8. novembra 1945, kada je prestao usled odbijanja tipografskih radnika da ga štampaju, zbog uvredljivih napada na ustanove DFJ. Izašlo je samo sedam brojeva. Sadržaj lista je usmeren na oštru kritiku zloupotreba vlasti, izbornog zakonodavstva i izbornih uslova uz insistiranje na političkim i građanskim slobodama. Najveći broj komentara potpisali su urednik Milan Grol ili potpredsednik stranke advokat Dragić Joksimović. Na naslovnoj strani prvog broja nalazio se poziv na apstinenciju Udruženih opozicionih stranaka. Režim je sistematski napadao list kao „izdajnički“, da služi stranim interesima, udara na tekovine NOB-a i slično. Iako se radilo o praktično jedinom opozicionom listu u Srbiji, ,,prema 130 frontovskih", protiv Demokratije je povedena opšta hajka. Ona se nije svodila samo na verbalne napade već se sprovodila, kako navodi list, i ,otimanjem brojeva iz ruku prodavaca, cepanjem, polivanjem benzinom i paljenjem i lista i odeće $i$ ruku onih koji Demokratiju prodaju“. ,... Borci protiv mračnjačkih i fašističkih ideja na nekoliko mesta palili su brojeve Demokratije kako je to radio i Hitler sa spisima koji nisu govorili njemu u prilog. U Dečanskoj ulici, igrali su kolo oko takve jedne vatre. Na Slaviji, jednom sirotom dečaku, koji je prodavao Demokratiju, prosuli su benzin na svežanj novina koji je držao u rukama i sa listom ispekli i dečakove ruke. Na kraju Grol poručuje: 'Slova mogu biti spaljivana, ideje i ljudi proganjani, ali će život teći samo po zakonima koje postavlja stvarnost, pogotovu kada je ona tako neumitno odlučujuća kao današnja svirepa teška stvarnost' “46 Demokratija povodom nedemokratske izborne atmosfere donosi satiričnu pesmu „Predizborka“:

Nemoguća to je zbrka / samo jedan konj se trka

ko je brži od zelenka? / sustiže ga samo senka!

To jahaču kvari slavu / pretiče ga konj za glavu

Al i njemu ćar je lepa / jer je brži on od repa. ${ }^{47}$

Režimska štampa je drugačije izvestila o ovom događaju: Politika donosi povodom spaljivanja Demokratije šturo i neodređeno saopštenje: „Juče, 18. oktobra ujutru, neke grupe građana većinom omladinaca, na raznim mestima Beograda, podstaknute a na nekim mestima i izazvane od elemenata koji rade na unošenju zabune i izazivanju nereda, izvršili su paljenje i cepanje lista $D e-$ mokratija“ “. ${ }^{48}$ Partijsko glasilo Borba je još konkretnije u oceni: „Juče 18. ov. m. izvesna lica, u želji da pred neprijateljima naše zemlje prikažu kako u DFJ vlada neredovno stanje, su pokušala da spaljuju dnevnik Demokratija. Zavedeni ovom provokacijom u ovu akciju su se umešali i izvesni neodgovorni elementi. Poziva se građanstvo da ne naseda ovakvim provokacijama i da ukaže punu potporu organima vlasti u gonjenju ovakvih neprijatelja naše zemlje. “49

\footnotetext{
46 Демократија, 18. і 25. 11. 1945.

47 „Песма предизборка“, Демократија, 1. 11. 1945.

48 Политика, 19. 10. 1945

${ }^{49}$ Борба, 19. 10. 1945.
} 
Tito je čak poručio sa predizbornog mitinga: „Desio se slučaj spaljivanja Demokratije, Grolovog lista. Jasno je da se ovim aktom želi prikazati kako se onemogućava raspačavanje ovog lista. Naši ljudi frontovci, nikad to neće uraditi. Naprotiv, frontovci su uglavnom kupci Grolove Demokratije jer i njih interesuje šta to Grol ima da kaže. Organi vlasti su dobili nalog da spreče ove provokacije. “50 Mnogo kasnije je izašlo na videlo da su za spaljivanje Demokratije, napade na kolportere, kao i za druge slične akcije (,defašizacija“ u Trećoj gimnaziji u Beogradu i dr.) bili odgovorni najpravoverniji članovi SKOJ-a, koji svakako to nisu mogli raditi bez „miga“ partije.

Demokratija je posle sedmog broja zabranjenog 8. novembra 1945 , konačno prestala da izlazi ,pošto su tipografski radnici odbili da štampaju izdajničke novine“. Ton glasnogovornika režima prema slobodi štampe radikalno se izmenio: „Oni su tu slobodu shvatili tako da pričaju šta hoće. Ali sloboda nije raspuštenost i raskalašnost. Ima izvesne osnove ta sloboda. Sloboda je za dobro naroda i ličnosti i za njihovo razvijanje... nisu shvatili slobodu da pljuju na sve i svašta.“"51 „Kod nas je sloboda štrajka. Koliko je meni poznato radnici su stupili u štrajk zbog toga što je list napadao i uvrijedio sindikate. Bilo je dosta protivzakonitosti u tom listu. Radnici su smatrali da ne treba da štampaju taj list. Oni imaju pravo štrajka i mi nemamo šta da se miješamo. Mislim da vlada nema nikakvog moralnog prava da im sugerira da oni moraju taj list da štampaju. Osim toga to dokazuje da su radnici kod nas subjekti. Oni sami mogu da utiču na izvjesne stvari. Tu se više ništa ne može izmijeniti“, obrazložio je Josip B. Tito. ${ }^{52}$ Osim javnih spaljivanja, upotrebljavani su i drugi metodi kako bi se list ugušio ili smanjio tiraž (prema Grolu, on je iznosio oko 150.000 primeraka) - onemogućavanje rasturanja lista zadržavanjem na pošti, pretnje činovnicima raznih ministarstava i državnih preduzeća koji su čitali list otpuštanjem iz službe, premlaćivanja kupaca i prodavaca, problemi s nabavkom hartije i slično. Vrhunac pritiska je bilo odbijanje sindikata tipografskih radnika da štampaju ,izdajnički list“, čime su praktično ugušene jedine prave opozicione novine u Srbiji u tom periodu. Još jedan list u DFJ, pre ovog, tipografski radnici su već odbili da štampaju. Reč je o Narodnom glasu, glasilu frakcije HSS-a oko udovice Marije Radić, čiji je urednik bio Ivan Bernardić. Zbog više priloga koji su označeni kao delovanje protiv tekovina NOB-a, objavljenih u prvom i jedinom broju ovog nedeljnog lista (koji je inače doživeo dva izdanja) i on je prošao kao i Demokratija, a Bernardić, iako u ratu u antifašističkom bloku, kasnije je osuđen na višegodišnju robiju.

Kratkog veka je bio i vanfrontovski list Novosti (počeo da izlazi 9. novembra 1945) koji je trebalo da izlazi tri puta nedeljno, a pojavila su se samo prva tri broja. Za razliku od Demokratije koja je bila stranački list, Novosti su prema sopstvenoj najavi počele da izlaze kao nezavisan list, poziva-

\footnotetext{
${ }^{50}$ Политика, 19. 10. 1945.

51 „Сретен Жујовић на предизборном митингу 9. новембра 1945“, Политика, 10. 11. 1945.

${ }^{52}$ V. Koštunica i K. Čavoški, n. d., 74.
} 
jući se na činjenicu da u Srbiji izlazi samo jedan poluzvaničan nezavisan list Politika, čime je nezavisna štampa monopolisana. Novosti su težile da nastave tradiciju istoimenog predratnog lista čiji je vlasnik bio Jovan Jovanović, vođa Zemljoradničke stranke, jer se već u prvom broju podseća na njegovu predistoriju. Uz to, odgovorni urednik lista Dušan Baranin bio je jedan od sekretara ZS. ${ }^{53}$

S druge strane, početak izlaženja lista je u neposrednoj korelaciji sa izlaskom jedne od frakcija ZS iz fronta. Premijer srpske vlade Blagoje Nešković izrekao je na predizbornoj konferenciji sledeći sud o listu, posle čega je ubrzo prestao da izlazi: „Danas je izašao neki list Novosti koji kaže za sebe da je nezavisni. To je u stvari, drugovi, agentura Milana Gavrilovića iz Londona najcrnjeg reakcionara među svom crnom emigrantskom reakcijom. Ta gospoda koja su pokrenula taj list sviraju, kao što bi rekli muzičari, drugu violinu Milanu Grolu, mada se predstavljaju kao nezavisni i samostalni... pojava te grupacije reakcionara upravo je grupisanje reakcije za borbu protivu naših naroda posle izbora. ${ }^{\text {"54 }}$

Obnovljen je i satirični list Jež, nekada izrazito opoziciono glasilo, sa „oštrom dlakom“; sada je potpuno povlađivao režimu napadajući i ismejavajući isključivo opoziciju. Povodom toga u Demokratiji se pojavio komentar: „Nekad si bio mlad i bujan. Gustu i oštru dlaku morali su ti šišati. Sad kao da su te izvadili iz naftalina. Omatorio si, odrtavio i penzionariš. Ne, bolje da se nisi pojavljivao, pokvario si nam jednu lepu uspomenu. I ispod makaza Stojadinovića i Cvetkovića, tvoje bodlje su se kostrešile. Sad olinjale pod frizurom Ozne, one ti se lepe za ćelu. Nekad si ti jeo druge, sad tebe jedu moljci - Odjavi se u rejonu pa natrag u naftalin. ${ }^{\text {" } 55}$ Partijsko glasilo Borba ali i uticajna i nezavisna Politika, kao i sva druga manje značajna glasila u zemlji, potpuno su se pretvorili u propagandni servis Fronta, odnosno KPJ. U isto vreme Vlada je otkazivala gostoprimstvo stranim novinarima koji su ,zloupotrebljavali“ slobodu informisanja „dajući netačne i zlonamerne informacije o stanju u Jugoslaviji“. Korespondentu američke agencije International News Service Meri Tauer otkazano je gostoprimstvo, na šta je pet stranih dopisnika uložilo protest zbog isključivosti jugoslovenskih vlasti koje smatraju da sve vesti, različite od zvaničnih, škode ugledu zemlje. ${ }^{56}$

\section{Izbori 11. novembra 1945. kao ozvaničenje partijske diktature}

Iako su izbori od 11. novembra 1945. doneli značajno proširenje biračkog prava (žene, vojnici i osobe iznad 18 godina), izborna klima nalikovala je pre na ratnu nego na mirnodopsku. Opozicija, budući nesaglasna sa izbornim zakonodavstvom, a još više sa atmosferom i uslovima za izbore,

\footnotetext{
53 „Зашто излазимо“, Новости, 9. 11. 1945.

${ }^{54}$ Новости, 13. 11. 1945.

${ }^{55}$ Демократија, 1. 11. 1945.

${ }^{56}$ Branko Petranović, Političke i pravne prilike za vreme Privremene vlade DFJ (Beograd: Institut društvenih nauka, 1969), 191.
} 
nemogućnošću slobodnog političkog delovanja i odsustvom medijske slobode, odlučila se 20. septembra 1945. za apstinenciju. No, i pored toga nije prestala da bude na meti režimske propagande. Etikete ,izdajnici“, „,narodni neprijatelji“, „reakcija“ svakodnevno su prišivane liderima opozicije. Na predlog Edvarda Kardelja 26. oktobra 1945, pod izgovorom „da bi se sprečilo rovarenje antidemokratske manjine koja bi htela da apstinencijom ospori valjanost tih izbora“, ustanovljena je tzv. kutija bez liste (u narodu prozvana ,ćorava kutija“). To je bio način da se onemogući da opozicija „svojata“ glasove onih koji ne izlaze na izbore. S druge strane, ona je trebalo da bude svojevrstan korektiv i dokaz demokratičnosti vlasti kojom bi se obezbedila stvarna mogućnost izbora. Istovremeno, i neka vrsta mamca za neke pristalice opozicije, kojim se htela povećati izlaznost i odgovoriti na propagandu opozicije koja je pozivala na apstinenciju. U takvoj atmosferi opozicija je pozivala da ako se već zbog straha ne može ostati kući da se glasa u ,ćoravu“ kutiju. Kao još jedna vrsta mamca biračima, na Politbirou CK KPJ 29. avgusta 1945. donesena je odluka da se za Skupštinu naroda naročito u Srbiji i Hrvatskoj postave dve zemaljske liste Narodnog fronta (dve biračke kutije u praksi). ${ }^{57}$

Dragoljub Jovanović u svojim memoarima navodi diskusiju o karakteru izbora sa Blagojem Neškovićem. Na Jovanovićevu primedbu da je vojska više puta glasala na izborima, Nešković je uzvratio da možda jeste, ali da su mnogi glasali i u ,ćoravu“ kutiju. ${ }^{58} \mathrm{Na}$ sednici Izvršnog odbora Narodnog fronta Srbije, Sreten Žujović je na pitanje zašto je ,,ćorava kutija“ zvečala odgovorio: „Nismo imali tekstila da obložimo sve.“ Tadašnji vojnik Uglješa Krstić o učešću vojske na izborima u valjevskom kraju kaže: „Tada su nam objasnili vojni zadatak na koji smo krenuli: po jedna baterija, oko pedesetak ljudi, odlazi svaka na po jedno biračko mesto i tamo glasa. Sve je sređeno, nemamo tamo ni s kim ni šta da razgovaramo, glasamo i nazad u kasarnu“. ${ }^{59}$ Komunistička partija je čak i posle ovakvih izbora prekrajala rezultate na mestima na kojima nije bila zadovoljna. Tako u depeši od 12. novembra 1945. koju je i ime Okružnog komiteta Kruševac potpisala Bosa Cvetić, sekretar Komiteta, stoji: „Dragi drugovi! Usled toga što su izbori u pojedinim srezovima podbacili, to se upućuje drug Zlatko Tomović koji će prema dobijenim uputstvima od ovog Komiteta u zajednici sa vama učiniti izvesne ispravke, tako da bi se procenat glasalih povećao i celokupna situacija u našem okrugu prikazala mnogo boljom nego što jeste. Smrt fašizmu, sloboda narodu“ 60

57 Politbiro CK KPJ 1945-1948, priredio Branko Petranović (Beograd: Arhiv Jugoslavije, 1995), 83.

${ }^{58}$ Д. Јовановић, н. д., књ. II, 136.

59 Navedeno prema: Бојан Димитријевић, Грађански рат у миру: улога армије и службе безбедности у обрачуну са политичким противничима Титовог режима 1944-1954 (Београд: Српска реч, 2003), 80.

60 Navedeno prema: Драгомир Бонџић, Жупа - Срез у Србији 1944-1945. Политика, просвета, култура (Александровац: Завичајни музеј Жупе, 2018), 63. U uglu ovog dokumenta, rukopisom Bose Cvetić stajalo je: „Da nateraju procenat sa Kopaonikom na $80 \%$ “ (Исто). 


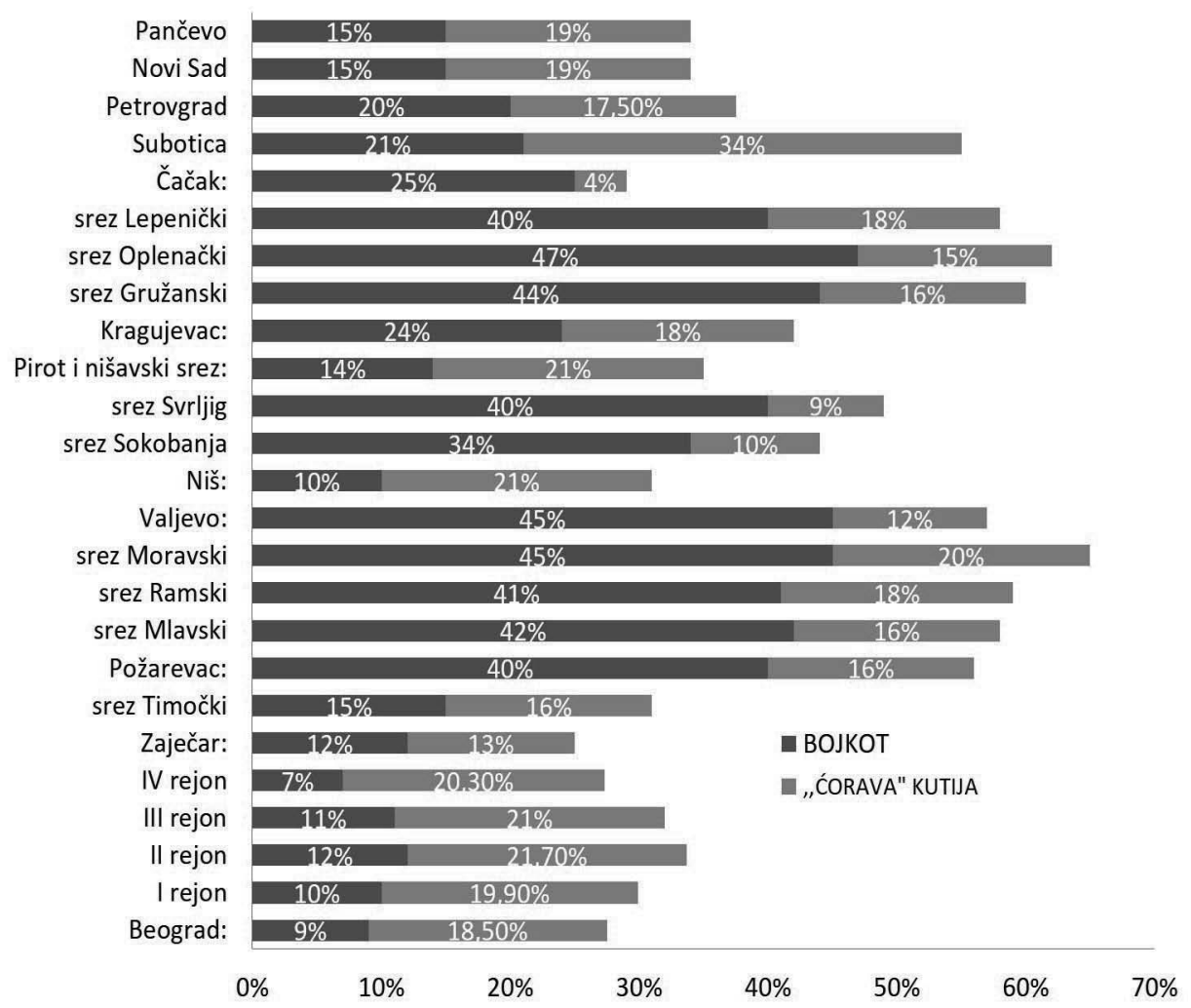

Najveći procenat neglasalih za Narodni front na izborima 11. novembra 1945. po mestima i srezovima

Celokupna predizborna atmosfera, medijski linč opozicije, strah i agresivna propaganda, posećenost predizbornih mitinga, obećavali su pobedu Narodnog fronta; rezultati izbora su mu doneli gotovo stopostotnu podršku. Sama ova činjenica dovodi u sumnju regularnost izbora. Međutim, i pored toga što je KPJ shvatala smisao izbora u postrevolucionarnom vremenu u njihovoj jednodušnosti, oni su ipak pokazali lokalne razlike i specifičnosti u pitanju podrške novoj vlasti. U svim federalnim jedinicama na izbore je izašlo 92-98\% birača, a u Srbiji oko $77 \%$. U Srbiji je bilo gotovo $30 \%$ onih koji nisu glasali za Narodni front, u Sloveniji 22\%, a u Makedoniji i Crnoj Gori svega 7\%. Broj kuglica u kutiji bez liste bio je znatno veći u sredinama koje su privredno, politički i kulturno razvijenije i gde je demokratska i parlamentarna tradicija imala dublje korene. U nekim srezovima u Srbiji poput Oplenačkog, Gružanskog, Valjevskog, Moravskog, Ramskog, Mlavskog, kao i u Subotici broj apstinenata i glasalih u „ćoravu kutiju“ bio je čak veći od broja glasalih za Front. U uslovima opšteg pritiska režima i represije to se moglo smatrati podvigom i svojevrsnom ,pobedom“ opozicije. Ipak, ovi izbori su označili i definitivnu smrt opozicije i de facto uvođenje jednopartijskog sistema koji će u Srbiji i Jugoslaviji potrajati gotovo pola veka. 


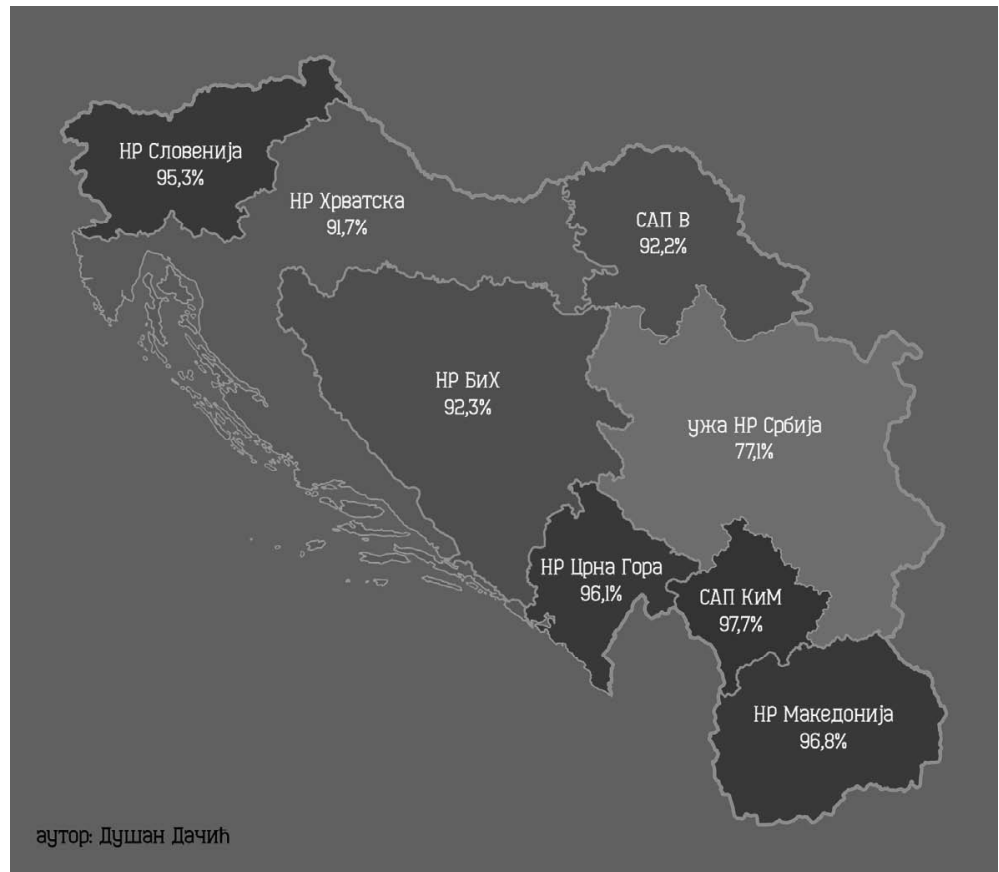

Procenat izašlih na izbore 11. novembra 1945. po republikama i pokrajinama

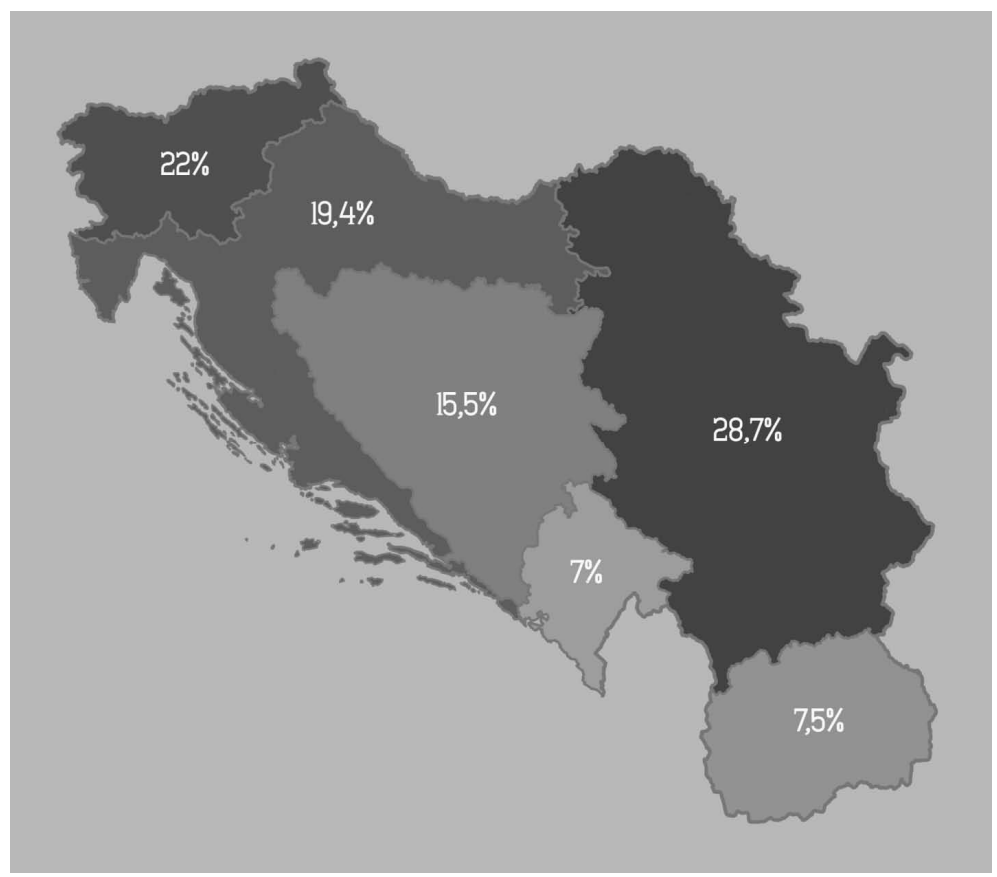

Procenat birača po republikama koji nisu glasali za listu Narodnog fronta (uključuje i apstinente) na izborima 11. novembra 1945. 
Zanimljivo je da anomalije u izbornom procesu, gušenje slobode štampe, otvoreno nasilje prema opoziciji i građanima, koje je u mnogim situacijama bilo zaista teško prevideti, nije bilo dovoljno stranim posmatračima da ospore legitimnost samih izbora. Veliki negativan odjek u domaćoj štampi imao je Memorandum opozicionih stranaka od 10. septembra 1945. koji su potpisali lideri stranaka u emigraciji Slobodan Jovanović, Jovan Banjanin, Vjećeslav Vilder, Mihailo Gavrilović i drugi i podneli Konferenciji savezničkih ministara inostranih poslova u Londonu. ${ }^{61}$ Politički efekat je, osim što je uznemirio duhove u zemlji, bio minimalan. U strogo poverljivom izveštaju iz američkih izvora od 25. septembra 1945. priznaje se da u Jugoslaviji ne postoje uslovi za demokratske izbore, ali se ipak u tome nije video osnov da se napadne politički poredak u Jugoslaviji koji je bio zasnovan na političkim dogovorima sa Jalte. Osim prigovora na manipulaciju armijom od 600.000 vojnika i strahom od političke policije u tom trenutku (kada je SSSR čvrsto stajao iza Tita), Zapad nije bio spreman na politički konflikt i zamašniji pritisak. ${ }^{62}$ Režim u Jugoslaviji je, kakavtakav, kao produkt međunarodnih sporazuma tokom 1945. uživao značajnu političku podršku vodećih zemalja antifašističke koalicije. Na taj način, odsustvo znatnije podrške opoziciji i svojevrsno, žmurenje“ nad nedemokratskim izborima i atmosferom u društvu zarad strateških interesa postaje razumljivije. Veliko je pitanje da su ovi izbori bili samo godinu-dve kasnije ili, preciznije, samo nekoliko meseci posle Čerčilovog govora u Fultonu i otpočinjanja Hladnog rata, kakav bi bio odnos zapadnih demokratija prema Titovom režimu. Tek su obaranjem američkih aviona (avgust 1946), te suočavanjem sa Titovom podrškom komunistima u Grčkoj i Tršćanskom krizom zapadni mediji ozbiljnije počeli da pišu o Titovoj diktaturi i represiji. Tako je posthumno 1947. od strane predsednika SAD Harija Trumana čak dodeljeno odlikovanje „prvom gerilcu porobljene Evrope“, generalu i ministru jugoslovenske vlade u Londonu Dragoljubu Draži Mihailoviću. Na taj način proces ozvaničenja partijske diktature u Srbiji i Jugoslaviji bio je završen. Formalna egzekucija „opozicije unutar fronta“ koja je nastupila u drugoj fazi revolucije, a čija je najpoznatija žrtva bio lider levih zemljoradnika dr Dragoljub Jovanović, bila je još lakši posao.

61 „Саопштење Танјуга поводом Меморандума политичке емиграције“, Политика, 26. 9. 1945; М. Павловић, н. д., 331-333.

${ }^{62} \mathrm{M}$. Павловић, $н$. . ., 315-318. 


\section{REFERENCE}

- Bondžić, Dragomir. Župa - Srez u Srbiji 1944-1945. Politika, prosveta, kultura. Aleksandrovac: Zavičajni muzej Župe, 2018.

- Cvetković, Srđan. Između srpa i čekića I. Likvidacija „,narodnih neprijatelja“ 1944-1953. Beograd: Službeni glasnik, 2015.

- Danilović, Rajko. Upotreba neprijatelja, Valjevo 1993.

- Dimitrijević, Bojan. Građanski rat u miru. Uloga armije i službe bezbednosti u obračunu s apolitičkim protivnicima Titovog režima 1944-1954. Beograd: Srpska reč, 2003.

- Dimitrijević, Bojan. "Intelligence and Security Services in Tito's Yugoslavia 1944-1966". Istorija 20. veka, br. 2, (2019), 9-28. https://doi.org/10.29362/ist20veka.2019.2.dim.9-28

- Dunjić, Živka S. Umčari. Beograd: Kulturno-prosvetna zajednica Srbije, 2019.

- Jovanović, Dragoljub. Medaljoni, knj. I-IV. Beograd: Službeni glasnik, 2008.

- Koštunica Vojislav, i Kosta Čavoški. Stranački pluralizam ili monizam: obnova i zatiranje posleratne opozicije. Beograd: Privredno-pravni priručnik, 1990.

- Lazić, Branko. Titov režim i pokret u Jugoslaviji, Gornji Milanovac: Dečje novine, 1992.

- Partizanska i komunistička represija i zločini u Hrvatskoj 1944-1946: dokumenti. Priredili Dizdar Zdravko, Vladimir Geiger, Milan Pojić, i Mate Rupić. Slavonski Brod: Hrvatski institut za povijest - Podružnica za povijest Slavonije, Srijema i Baranje, 2005.

- Pavlović, Momčilo. Za Tita ili za kralja. Izbori za Ustavotvornu skupštinu 11. novembra 1945. Beograd: Institut za savremenu istoriju, 2019.

- Petranović, Branko. Političke i pravne prilike za vreme Privremene vlade DFJ. Beograd: Institut društvenih nauka, 1969.

- Politbiro CK KPJ 1945-1948. Priredio Branko Petranović. Beograd: Arhiv Jugoslavije, 1995.

- Radelić, Zdenko. „Narodni glas“, Časopis za suvremenu povijest, br. 1, Hrvatski institut za povijest, Zagreb, 1993.

- Radelić, Zdenko. Hrvatska u Jugoslaviji 1945-1991, od zajedništva do razlaza, Zagreb: Hrvatski institut za povijest, Školska knjiga, 2006. 
SRĐAN CVETKOVIĆ, PhD, Senior Research Associate

Institute for Contemporary History

Belgrade, Republic of Serbia

scvetkovic72@gmail.com

\title{
SUSPENSION OF PARLIAMENTARY PROCESS AND FORMS OF PRESSURE ON THE OPPOSITION BEFORE THE ELECTIONS IN SERBIA IN NOVEMBER 11, 1945
}

\begin{abstract}
Summary
The process of suspending parliamentary democracy and introducing a one-party dictatorship in Socialist Yugoslavia went through three phases but was never formally legitimized. In the first phase, before establishing power in the election on 11 November 1945, the Communist Party of Yugoslavia first eliminated the opposition, acting with monopoly on institutions, State Security, courts, and all-important social organizations, as a part of a broad coalition of the People's Front. The second phase of illusory political pluralism implied establishing a one-party monopoly in the Front, in which recent satellites slowly ideologically merged. In the third phase all social forces found themselves in one monolithic organization, which became the ideological transmission of the Communist Party for influencing the masses, under the new name of SSRNJ (Socialist Alliance of Working People of Yugoslavia). The election on 11 November 1945 brought significant suffrage extension (women, soldiers, people over 18), but also a completely narrowed choice. The election climate was everything but democratic. Disagreeing with the election legislation, atmosphere, impossibility of free political engagement as well as the absence of freedom of the media, the opposition opted for an election boycott on 22 September 1945. By means of splitting parties and fusing their pro-government wings, political processes against opposition leaders, suppression of independent media, and similar techniques, the Communist Party of Yugoslavia soon paved the way to one-party dictatorship. The suspension of even an illusory form of party pluralism as well as the transition from a hegemonic party system to a one-party system happened more rapidly and with less resistance than in other Eastern European countries. The Communist Party of Yugoslavia's misuse of the strong antifascist resistance movement to brutally liquidate political opponents at the end of the war contributed to this process. In this kind of atmosphere, the election brought an almost $100 \%$ victory of the People's Front and marked the definitive demise of the opposition as well as the establishment of a one-party system that would last for almost half of a century.
\end{abstract}

KEYWORDS: Serbia, Elections, Democracy, Political Culture, Communism, Parliamentarism 